\title{
ANALISIS KREATIVITAS MENGGAMBAR ANAK MELALUI KEGIATAN MENGGAMBAR
}

\author{
Dewi Sartika Ukar', Bahran Taib², Bujuna Alhadad ${ }^{3}$ \\ Universitas Khairun Ternate \\ Fakultas Keguruan dan Ilmu Pendidikan \\ Jl. Bandarah Sultan Baabullah Kota Ternate Utara, Kotak Pos 53 Ternate 977328 \\ Telepon: (0921) 3110905-Faksimili 0921-3110901 \\ Email: dewiukar0102@gmail.com², taibbahar4685@gmail.com², bujunaalhadad@gmail.com³
}

\begin{abstract}
Abstrak: Kreativitas menggambar anak melalui kegiatan menggambar adalah upaya stimulasi perkembangan anak dengan merencanakan dan memilih pelaksanaan kegiatan menggambar anak usia 56 tahun. Kegiatan menggambar sering tidak dipilih dalam kegiatan pembelajaran dan guru cenderung memilih kegiatan mewarnai. Kreativitas erat hubungannya pula dengan aktivitas berkesenian termasuk kreativitas seni rupa yang diwujudkan ke dalam aktivitas menggambar. Menggambar salah satu kegiatan yang disenangi anak-anak, dalam memudahkan anak menggambar guru dapat memilih jenis kegiatan menggambar bebas dengan menghubungkan titik-titik hingga membentuk sebuah gambar. Berdasarkan kajian literatur dapat disimpulkan bahwa kegiatan menggambar pada anak usia dini dapat meningkatkan kreativitas menggambar anak semenjak dini dan bermanfaat dalam menyerap pelajaran dan menciptakan suasana belajar mengajar yang menyenangkan.
\end{abstract}

Kata Kunci: Kreativitas Menggambar, Kegiatan Menggambar

\begin{abstract}
Children drawing creativite through Drawing activity is stimulation effort of children development with planning and choosing the activity for childrean aged 5-6 years. The drawing activity is not usually chosen in learning process and the teachers tends to choose coloring activity. The creativity is also related tor artisitic activities, including visual arts creativity, which is manisfested in drawing activities. The Drawing activity is one of the activities that children love, in making it easier for children to draw, the teacher can choose the type of drawing activity animpeded by connecting the dots to make the picture. Based on library research the writer can conclude that the drawing activity can improve the children creativity since early and useful in learning and create the fan learing process.
\end{abstract}

Keyword: Drawing creativity, Drawing activity 


\section{A. Pendahuluan}

Menggambar adalah salah satu kegiatan yang digemari anak. Kegiatan menggambar sangat sering dipilih guru dalam rancangan dan pelaksanaan pembelajaran pada Pendidikan Anak Usia Dini. Guru tidak perlu memaksa anak untuk melakukan kegiatan menggambar karena anak dengan mudah berkreasi, sesuai dengan teori yang dikemukakan Olivia (2013:2), mengatakan bahwa, menggambar bebas merupakan aktivitas mencoret-coret suatu media kertas yang merupakan hasil dari ide dan gagasan pemikiran seseorang, mengenai apa yang dilihatnya atau apa yang disampaikan orang lain, baik itu berupa suatu objek yang ada dilingkungan, maupun murni dari hasil pemikiran seseorang mengenai sesuatu sehingga menghasilkan kepuasan tersendiri.

Para ahli berpendapat bahwa ada hubungan yang erat antara kecerdasan dengan kreativitas. Seorang penulis kreatif bernama Eng Hock Chia (dalam Anik Pamilu, 2007: 11) menyatakan bahwa di dalam Inteligenci Quotient (IQ), bakat, dan kreativitas sebagian besar berasal dari pengaruh lingkungan dan keterampilan. Menurut Seto Mulyadi (dalam Anik Pamilu, 2007: 11), antara kreativitas dan kecerdasan itu mempunyai hubungan yang sangat erat. Oleh karena itu, anak tidak boleh hanya dididik agar menjadi anak yang cerdas saja, akan tetapi harus pula dididik agar menjadi anak yang kreatif dan mempunyai emosi yang stabil. Seto Mulyadi (dalam Anik Pamilu, 2007: 11) juga menyatakan bahwa orientasi Pendidikan pada saat ini, baik di sekolah maupun di rumah cenderung dominan pada permasalahan "bagaimana menciptakan anak yang cerdas secara logika, matematika, dan bahasa", sementara untuk kecerdasan yang lain masih kurang mendapatkan perhatian dan porsi yang semestinya.

Wahyudin (2007: 6) menyatakan ibarat bangunan, pondasi bangunanlah yang akan menentukan wujud bangunan finalnya. Semakin kuat dan tinggi bangunan yang akan didirikan di atasnya, maka semakin dalam dan kuat pondasi yang harus dibangunnya. Untuk membangun pondasi yang kuat serta dalam, membutuhkan waktu yang lama.

Demikian pula dengan kreativitas anak, seperti dikatakan Wahyudin (2007: 6-7), sebagai pondasi, anak sangat membutuhkan penggarapan yang serius, tetapi karena sifat pondasi tersebut tidak tampak maka banyak orangtua yang mengabaikannya. Orangtua menganggapnya sepele dan tidak penting.

Selanjutnya Wahyudin (2007: 7) menjelaskan bahwa pada kenyataannya sikap orangtua menyepelekan makna kreativitas sebab proses kreatif seorang anak cenderung merepotkan orangtua. Dalam hal ini orangtua semakin acuh dan tidak mengambil langkahlangkah penting untuk membangkitkan dan membina kreativitas anak.

Wahyudin (2007: 7) juga menjelaskan bahwa apabila kreativitas ini tidak dikembangkan maka setelah dewasa dapat menjadi pribadi yang lembek, merepotkan orangtua, tidak memiliki inisiatif, dan tidak bertanggung jawab.

Kreativitas erat hubungannya pula dengan aktivitas berkesenian termasuk kreativitas seni rupa yang diwujudkan ke dalam aktivitas menggambar. Sumanto (2005: 10) menyatakan, kreativitas adalah bagian dari kegiatan berproduksi atau berkarya termasuk dalam bidang seni rupa. Hal ini didasari oleh lekatnya proses penciptaan sebuah karya seni dengan keterampilan dalam berkreativitas.

Merangsang serta memupuk kreativitas semenjak usia dini adalah salah satu upaya yang dapat dilakukan orangtua untuk mendapatkan anak yang kreatif. Anik Pamilu (2007: 2) menyatakan bahwa anak yang kreatif suka berkreasi. Dengan berkreasi ia akan dapat mengaktualisasikan dan mengekspresikan dirinya. Selanjutnya Anik Pamilu (2007: 69) menjelaskan bahwa melakukan olah seni termasuk seni rupa merupakan salah satu aspek 
terpenting untuk meningkatkan kreativitas anak. Bukan berarti anak harus bisa menggambar atau melukis sebaik Affandi.

Sesungguhnya kegiatan seni rupa merupakan sejumlah kegiatan dari mewarnai, menggambar, membentuk, dan lain sebagainya. Anik Pamilu (2007: 69) menegaskan bahwa pada usia prasekolah, kemampuan imajinasi dan belajar seorang anak sangatlah besar. Anik Pamilu (2007: 69) menegaskan bahwa dengan memberikan kegiatan permainan kepada anak, aktivitas kesenian dapat membantu anak untuk mengembangkan imajinasi dan kreativitasnya.

Termasuk aktivitas menggambar. Anik Pamilu (2007: 69) menjelaskan bahwa kegiatan menggambar merupakan sarana yang tepat dan sesuai untuk anak usia Taman Kanak-kanak dalam rangka mengaktualisasikan, mengeskpresikan diri dan membantu anak untuk mengembangkan serta meningkatkan imajinasi dan kreativitasnya melalui kegiatan mengeksplorasi warna, tekstur, dan bentuk dengan media menggambar yang dituangkan sesuka hatinya, bebas, spontan, kreatif, unik, dan bersifat individual.

Berdasarkan fakta yang terjadi di lapangan dan literatur maka penulis tertarik untuk membahas analisis kreativitas menggambar anak melalui kegiatan menggambar.

\section{B. Kajian Teori}

Dalam Permendiknas 137 Tahun 2014, Anak usia 5-6 tahun sudah dapat mengekspresikan kegiatan bentuk seni rupa salah satunya adalah membuat gambar secara detail dan memiliki bentuk, mampu mengembangkan ide, serta anak mampu menciptakan karya baru.

Penelitian Sundari, Eliyati, \& Hasmalena (2018) yang mengatakan bahwa kemampuan menggambar anak mengalami peningkatan setelah melakukan penelitian dengan judul Peningkatan Kreativitas Anak Melalui Kegiatan Menggambar Bebas Pada Anak Kelompok B di TK Kartika II-1 Palembang.

Supriadi mengemukakan dalam Rachmawati \& Kurniati (2010) ialah kepiawaian yang dimiliki seseorang untuk menghasilkan sesuatu yang berbeda dari yang pernah ada, baik dari segi gagasan maupun karya nyata disebut dengan kreativitas. Kreativitas merupakan kebolehan agar tercipta atau daya cipta Poerwadarminta (1998), kreativitas merupakan suatu bentuk mental seseorang sebagai kreasi agar tercipta sesuatu yang baru. Kegiatan otak yang teratur komprehensif, imajinatif untuk mendapatkan hasil yang maksimal disebut juga dengan kreativitas.

Menurut Lowenfeld (dalam Sumanto, 2006: 9) karakteristik kreativitas dalam berkarya senirupa adalah seperangkat kemampuan seseorang meliputi:

1. Kepekaan mengamati berbagai masalah dengan indera;

2. Kelancaran dalam mengeluarkan berbagai alternatif pemecahan masalah;

3. Keluwesan melihat atau memandang suatu masalah serta kemungkinan jawaban pemecahannya;

4. Kemampuan merespon atau membuahkan gagasan dalam originalitas yang biasa atau umum ditemukan;

5. Kemampuan yang berkaitan dengan keunikan cara atau mengungkapkan gagasan dalam menciptakan karya seni;

6. Kemampuan mengabstraksi hal-hal yang bersifat umum dan mengaitkannya menjadi hal-hal yang spesifik;

7. Kemampuan memadukan atau mengkombinasikan unsur-unsur seni menjadi karya seni yang utuh; 
8. Kemampuan menata secara terpadu dari keseluruhan unsur-unsur seni ke dalam tatanan yang selaras.

Sumanto (2006: 10) menegaskan bahwa proses penciptaan sebuah karya dari kreativitas menggambar bukan hanya berupa kepandaian secara fisik saja dalam proses berkaryanya, melainkan juga termasuk kemampuan mencurahkan segenap potensi pribadi, baik berupa bakat, kepekaan, pengalaman, dan sebagainya. Sumanto (2006: 10) menyebutkan proses penciptaan sebuah karya tersebut adalah sebagai berikut:

1. Mengolah media ungkap sesuai alat yang digunakan sewaktu berkarya;

2. Ketepatan dalam mewujudkan gagasan ke dalam karya;

3. Kecekatan atau keahlian tangan dalam menerapkan teknik-teknik dalam berkarya.

Syahputra, A (2012) menyebutkan 10 cara meningkatkan kreativitas anak yaitu:

1. Berkreasi setiap hari;

2. Menggunakan sisi kedua tubuh dalam beraktivitas;

3. Memiliki tokoh yang diteladani dan diidolakan;

4. Meningkatkan perbendaharaan kata pada anak;

5. Melatih kemampuan mendengar anak;

6. Menggunakan warna-warni saat bermain;

7. Melatih ketelitian anak;

8. Memberikan liburan yang kreatif;

9. Jangan terlalu serius dalam mendidik anak;

10. Melatih kemampuan otak anak.

Dengan demikian kreativitas perlu di tingkatkan dengan melibatkan anak secara aktif dalam berkegiatan, kegiatan menggambar dapat dipilih dalam pengembangan kreativitas. Kreativitas menggambar memiliki karakteristik yakni: kreativitas menggambar merupakan proses yang mengarah pada sebuah penciptaan sesuatu hal yang baru. Penciptaan tersebut timbul dari sebuah pemikiran, merupakan suatu cara berpikir, kemampuan untuk mencipta gambar-gambar yang dihasilkan dari gagasan-gagasan dan originalitas, serta merupakan bentuk imajinasi.

Menggambar merupakan aktivitas spontan bagi anak untuk menggambar. Anak "menggambar" sesudah mereka mampu memegang pensil atau alat tulis yang lain. Anak dapat melalukan hal itu mulai berusia kurang lebih 52 minggu. Menggambar merupakan suatu gerakan motoris yang global bagi anak; seluruh badan seakan-akan terlibat melakukan gerakan itu (Haditono, 2001).

Victor Lowenfeld dalam Dewobroto (2005) mengemukakan tahapan perkembangan anak lewat menggambar yaitu:

1. Umur 2-4 tahun (Masa Mencoreng/Scribling Period) aktivitas motorik yang terwujud dalam goresan tebal tipis dengan arah yang belum terkendali dan warna tidak begitu penting.

2. Umur 4-7 tahun (Masa Pra Bagan/Pre Schematic Period)aktivitas motorik pada usia ini sudah terkendali. Ia sudah bisa mengkoordinasikan pikiran dengan emosi dan kemampuan motoriknya. Anak mulai menggambar bentuk yang berhubungan dengan alam dan sekitarnya. Pada mulanya bentuk sulit dikenali, misalnya manusia, rumah, dan pohon, perhatian lebih tertuju pada hubungan antara gambar dan objek dari pada warna dan objek.

Dari uraian diatas tentang tahapan perkembangan lewat menggambar anak pada usia 5-6 tahun (kelompok B) termasuk dalam masa pra bagan/pre schematic period, agar 
dapat membantu anak untuk segera mengenali objek gambar maka kegiatan gambar yang diberikan pada anak adalah kegiatan gambar tematik.

Kegiatan menggambar dapat dibedakan berdasarkan pada kebutuhan, fungsi dan cara pembuatannya. Tarja Sudjana, dkk. (2001: 2) mengemukakan bahwa pada masa sekarang ini, menggambar banyak dibutuhkan dan digunakan dalam berbagai kegiatan, dapat dicontohkan gambar yang dipergunakan untuk kepentingan ilmu pengetahuan, tekhnologi, ekonomi, dan pendidikan. Sejalan dengan kebutuhan tersebut, maka muncul berbagai macam jenis menggambar sesuai dengan fungsinya, Tarja sudjana, dkk. (2001: 2) mendeskripsikannya antara lain:

1. Menggambar bentuk;

2. Menggambar dekoratif;

3. Menggambar ekspresif;

4. Menggambar illustratif;

5. Menggambar disain reklame;

6. Menggambar perspektif.

Sumanto (2005: 48) membedakan jenis kegiatan menggambar yang didasarkan pada cara pembuatannya, yang di antaranya adalah:

1. Menggambar secara bebas sesuai alat gambar yang digunakan tanpa memakai bantuan alat-alat lain seperti mistar, jangka dan sejenisnya. Terdapat ciri gambar yang bebas, spontan, kreatif, unik dan bersifat individual.

2. Menggambar yang dibuat dengan bantuan peralatan mistar, penggaris, jangka, busur derajat, dan sablon. Terdapat ciri yang terikat, statis, dan tidak spontan.

Sumanto (2005: 48) menegaskan bahwa pembelajaran menggambar yang sesuai di Kelompok Bermain atau di Taman Kanak-kanak bukanlah menggambar yang dibuat dengan bantuan mistar dan sejenisnya melainkan adalah macam menggambar yang bersifat bebas itulah yang dilatihkan kepada anak. Yang antara lain macamnya adalah melatihkan menggambar bebas, menggambar imajinatif, mewarnai gambar dan lainnya.

Dari definisi-definisi tersebut di atas maka dapat ditarik kesimpulan bahwa jenisjenis kegiatan menggambar dapat dibedakan berdasarkan cara pembuatannya ataupun sesuai dengan fungsinya. Kegiatan menggambar yang dapat diberikan pada anak usia dini antara lain: menggambar bentuk, menggambar tematis, menggambar non tematis, dan menggambar bebas. Ada pun jenis menggambar dalam penelitian ini adalah jenis menggambar bebas, menggambar bentuk dan menggambar tematis. Beberapa teknik menggambar dapat dipakai dalam menggambar bebas namun penulis menekankan pada kreativitas menggambar dengan bentuk dasar berupa melengkapi titi-titik yang sebelumnya sudah dibuat dengan tujuan setelah anak menghubungkan titik tersebut anak telah menggambar bentuk yang diinginkan.

Aktivitas menggambar yang dapat menstimulasi kreativitas menggambar yaitu aktivitas menggambar yang diawali dengan menggambar bentuk dasar, kemudian anak menambahi dengan goresan gambar bentuk-bentuk lainnya pada gambar bentuk dasar tersebut, yang kemudian anak diperbolehkan untuk mewarnainya secara bebas, sehingga melalui proses tersebut anak dapat menghasilkan sebuah karya gambar yang sifatnya unik dan kreatif. Anak hendaklah diberi kebebasan untuk memilih bentuk gambar yang diminati, pendidik dan orang tua dapat mendampingi anak selama kegiatan menggambar dengan cara menyiapkan bentuk gambar kemudian anak dapat memilih bentuk yang diminati. 
Stimulasi kemampuan menggambar sangat dibutuhkan anak, agar kreativitas menggambarnya berkembang kebebasan yang utama, tidak ada paksaan sehingga kegiatan lebih menyenangkan.

Oleh karenanya pada kajian penulisan ini akan membahas tentang fungsi aktivitas menggambar yang dapat digunakan sebagai kegiatan pembelajaran dalam rangka pengembangan kreativitas menggambar pada anak usia dini.

Banyak pakar mengutarakan tujuan dan fungsi menggambar bagi anak usia dini. Menurut Ade Hensuska (2005: 2) melalui aktivitas menggambar, anak dapat menorehkan perasaan, mengungkapkan perasaan, mengungkapkan keinginan, dan menceritakan pengalaman. Selain itu dengan aktivitas menggambar juga bisa melatih kemampuan kreatif anak.

Hal ini sejalan dengan Hajar Pamadhi (dalam Saiful Haq, 2008: 4) yang menyatakan bahwa menggambar memiliki tujuan yang antara lain: a) alat untuk mengutarakan/ekspresi isi hati, pendapat maupun gagasan; b) media fantasi, imajinasi dan sekaligus sublimasi; c) stimulasi bentuk ketika lupa atau untuk menumbuhkan gagasan baru; dan d) alat untuk menjelaskan bentuk serta situasi. Sumanto (2005: 49) menyatakan bahwa tujuan aktivitas menggambar pada pendidikan anak usia dini ini dimaksudkan agar kemampuan berolah senirupa yang yang diwujudkan dengan keterampilan mengungkapkan ide, gagasan, pengalaman, pengamatan kedalam goresan garis, bentuk, dan warna sesuai alat gambar yang digunakannya.

Dengan demikian pembelajaran menggambar yang sesuai untuk pendidikan anak usia dini adalah dengan jenis menggambar bebas, menggambar imajinatif, dan mewarnainya.

Banyak faktor-faktor yang mempengaruhi mengapa kegiatan menggambar perlu diberikan dan dimasukkan ke dalam kegiatan pembelajaran pada Pendidikan anak usia dini. Sumanto (2005: 23) menjelaskan bahwa sejalan dengan fungsi dan tujuan pendidikan anak, maka untuk pengembangan seni rupa (termasuk menggambar) pada pendidikan anak, hendaknya dapat difungsikan untuk membina keterampilan dan kemampuan anak dalam berinteraksi dengan lingkungan, dan sebagai sarana untuk memperoleh pengalaman visual estetis berolah senirupa.

Diah Sukrisnawati dan Syamsuri Jari (1993: 38) menyatakan tidak kalah dengan berbagai cabang kesenian lainnya, seni rupa juga bisa digunakan untuk menunjang keefektifan dan efisiensi pada pengajaran. Karena pada dasarnya anak-anak suka sekali menggambar, mewarnai, melipat dan menempel kertas serta membuat dan menyusun sesuatu. Hal ini semua disebabkan karena nalurinya yang besar untuk mengetahui, menyelidiki, mencoba dan berbuat.

Ditegaskan pula oleh Diah Sukrisnawati dan Syamsuri Jari (1993: 38) bahwa bila digunakan sebaik-baiknya, seni rupa sangat bermanfaat untuk mempermudah dan mempercepat anak-anak dalam menyerap bahan pelajaran, memfokuskan perhatian mereka terhadap pengajaran, dan lebih dari itu adalah menciptakan suasana belajar mengajar yang menyenangkan.

Dalam Tim Redaksi Ayah bunda (2002: 10) dijelaskan bahwa anak mempunyai dorongan emosi yang butuh pelepasan. Oleh karenanya, sesuai dengan kondisi emosinya, ekspresi kesedihan, kekhawatiran dan kondisi-kondisi emosi lainnya dapat terlihat dari garis, bentuk, tema, dan warna-warna yang digunakan anak dalam gambarnya. Mengandung makna bahwa aktivitas menggambar ini perlu diberikan pada pendidikan anak, dengan alasan untuk pelepasan dan dorongan emosi yang ada dalam diri anak. 
Berdasarkan kajian literatur dapat dihipotesiskan bahwa kegiatan menggambar dapat membantu anak dalam pembelajaran terutama kreatifitas. Kegiatan menggambar memberikan pengalaman visual bagi anak untuk mencoba dan berbuat hal-hal baru dalam hasil karyanya yang tentunya semua itu dibantu oleh guru dengan cara melakukan perencanaan pembelajaran kegiatan menggambar, memilih kegiatan meggambar dengan mempertimbangkan perkembangan anak dari segi usia, individu dan lingkungan anak. Sebagai contoh menggambar bentuk dengan cara menghubungkan titik-titik sehingga menjadi suatu objek gambar yang diinginkan anak.

\section{Kesimpulan}

Berdasarkan kajian literatur dapat disimpulkan bahwa kegiatan menggambar pada anak usia dini dapat meningkatkan kreativitas menggambar anak semenjak dini dan bermanfaat dalam menyerap pelajaran dan menciptakan suasana belajar mengajar yang menyenangkan dengan memperkaya kegiatan menggambar salah satunya menghubungkan titik hingga menjadi objek gambar. Anak dapat diberikan kebebasan dalam menentukan warna dalam kegiatan menggambar.

\section{DAFTAR PUSTAKA}

Ade Hensuska. (2005). Panduan Dasar Menggambar dengan Pensil untuk Anak Mudah \& Menyenangkan. Tangerang: PT. Kawan Pustaka.k-anak

Anik Pamilu. (2007). Mengembangkan Kreativitas dan Kecerdasan Anak. Yogyakarta: Citra Media.

Dewabaroto,B.T.( 2005).Gaya lukis anak-anak sebagai Acuan Penciptaan Karya Seni Lukis",Surya Seni, Jurnal Penciptaan dan Pengkajian Seni, Vol.1:01 Februari,2005.

Diah Sukrisnawati \& Syamsuri Jari. (1993). Seni Sebagai Media Pengembangan Kehidupan Beragama Taman Kanak-kanak 'Aisyiyah Bustanul Athfal, Jakarta: Pimpinan 'Aisyiyah Bagian Pendidikan dan Kebudayaan.

F.J. Monks, Knoers, Siti Rahayu Haditono, 1992. Psikologi Perkembangan Pengantar Dalam Berbagai Bagiannya, Yogyakarta: UGM Pres

Hajar Pamadhi, Evan Sukardi S., \& Azizah Muis. (2010). Seni Keterampilan Anak. Jakarta: Penerbit Universitas Terbuka.

Olivia, F. (2013). Gembira Bermain Coret-Coret. Jakarta: PT Elex Media Komputindo

Penelitian Sundari, Eliyati, \& Hasmalena (2018). Peningkatan Kreativitas Anak Melalui Kegiatan Menggambar Bebas Pada Anak Kelompok $B$ di TK Kartika II-1 Palembang.https://ejournal.unsri.ac.id/index.php/tumbuhkembang/article/downloadSup pFile/7580/1102. Diakses pada 20 Juni 2020.

Peraturan Menteri Pendidikan dan Kebudayaan Republik Indonesia Nomor 137 Tahun 2014 tentang Standar Nasional Pendidikan Anak Usia Dini.

Poerwadarminta, W. J. S. (1998). Kamus Besar Bahasa Indonesia (KBBI). Jakarta: Balai Pustaka

Sumanto. (2005). Pengembangan Kreativitas Senirupa Anak TK. Jakarta: Departemen Pendidikan Nasional, Direktorat Jenderal Pendidikan Tinggi, Direktorat Pembinaan Pendidikan Tenaga Kependidikan dan Ketenagaan Perguruan Tinggi. 
Sumanto.(2005) Pengembangan Kreativitas Seni Rupa Anak TK. Jakarta: Departemen Pendidikan Nasional, Dirjen Pendidikan Tinggi, Direktorat Pembinaan Pendidikan Tenaga Kependidikan dan Ketenagaan Pendidikan Tinggi.

Sumanto. (2006). Pengembangan Kreativitas Senirupa Anak SD. Jakarta: Departemen Pendidikan Nasional, Direktorat Jenderal Pendidikan Tinggi, Direktorat Ketenagaan Perguruan Tinggi.

Supriadi. 2000. Kreativitas, Kebudayaan, dan Perkembangan Iptek. Bandung: Alfabeta.

Syahputra, Ansyari.(2012), "10 Cara Meningkatkan Kreativitas Anak" http://blogansyari.blogspot.com

Tarja Sudjana, Irin Tambrin, Tity Soegiarty, \& Maman Tocharman. (2001). Seni Rupa untuk SLTP Kelas I. Bandung: Penerbit Grafindo Media Pratama.

Tim Redaksi Ayahbunda. (2002). Dari A Sampai Z tentang Perkembangan Anak Buku Pegangan untuk Pasangan Muda. Jakarta: PT. Gaya Favorit Press. Wahyudin. (2007). A to Z Anak Kreatif. Jakarta : Gema Insani. 